\title{
Strategic communication concept implemented through the corporate political activities - suggested strategy modeling
}

\section{Miroslav Mitrović}

Strategic Research Institute, University of Defense, Belgrade, Serbia

\begin{abstract}
The concept of strategic communication is actual in all spheres of contemporary social and business life. The paper analyzes the concept, structure, and forms of strategic communication based on a wide base of scientific and professional literature. Paper consider correlation between strategic communication, integrated business communication, and corporate communications. A particular overview is devoted to corporative political activities as part of strategic communication. In the closing section of the work, a model of planning and implementation of corporate political activities based on the STAP model of the lobbying strategy with the development of individual communication tactics is presented. The basis of the communication matrix for different groups of the public are proposed through various tactics applicable in the framework of corporative political activities. Overall contributes to defining the notion of strategic communication as well as to the place and role of corporate political activities as a special form of strategic communication.
\end{abstract}

\section{Keywords}

Strategic communication, corporative communications, corporative political activities, lobbying, integrated business communication.

\section{Introduction}

Strategic communication is a part of social activities in the growing and development phase. Immaturity of phenomena contributes to its undefined and sometimes unclear understanding. (Hallahan, Holtzhausen, Van Ruler, Verčić \& Sriramesh, 2007, p. 28). Dynamic of development of phenomena contribute to a conclusion that not all communications are strategic, as well as that not all strategic communications are conducted against positive goals (Holtzhausen \& Zerfass, 2015).

Defining of strategic communication is a contemporary process. By Oxford Bibliographies (OB, 2018) Strategic communication (SC) is a term used to denote the higher-level concerns behind communicative efforts by organizations to advance organizational mission. Strategic communication as communication aligned with the company's overall strategy, to enhance its strategic positioning (Argenti, Howell \& Beck, 2005). Contemporary understanding of strategic communication is strongly based on definition suggested by Hallahan and associates, where strategic communication, in its broadest sense, could be understood as "communicating purposefully to advance (the organization's) mission" and "implies that people will be engaged in deliberate communication practice on behalf of organizations, causes, and social movements" (Hallahan et al., 2007, p. 4).

\section{When is communication strategic?}

We could agree that communication is strategic when it is completely consistent with a corporation's mission, vision, values and is able to 
enhance the strategic positioning and competitiveness of the organization (FTL, 2018). Thorson (2013) suggests that strategic communication should integrate all those communications that are associated with organizational goals and strategies, whether SC has focus on presenting and promoting goals and strategies or concentrated on driving its development. In other words, for some, strategy precedes strategic communication; for others, strategic communication also constitutes a strategy.

Holtzhausen emphasizes that strategic communication focusing on corporative and economy categories, suggesting that communicative entities "cover the full spectrum of economic and social sectors, such as trade and industry, politics, non-profit and government agencies, activist groups, and even celebrities in the sports and entertainment industries" (2008, p. 4849). There, we could find an indication that strategic communication is wider and broader phenomenon than marketing and public relation, or even integrated communication. In fact, strategic communication covers all listed, but also more activities from spectra of inner and out communications, which contributes to enhancing of organization position and mission fulfillment. In search of a more comprehensive, single definition of Holtzhausen and Zerfass (2013, p. 74) proposed: "Strategic communication is the practice of deliberate and purposive communication that a communication agent enacts in the public sphere on behalf of a communicative entity to reach set goals".

It could be said, that strategic communication is the overall communication efforts of the organization to achieve maximum possible fulfillment of their mission thought most effective communication with all their target publics.

The role of strategic communication is to ensure information transfer and creation of relation upon them among of all public segments, which are in correlation with the organization. This perspective includes the concepts of strategic message design, management of culture, and total quality management (Holtzhausen, 2002).

\subsection{Determination of Strategic Communication}

According to Paul (2011, p. 7), strategic communication in attending to be successful must include the communicative content and signals of actions, images, and policies. He suggests an understanding of the term as:

- enterprise level strategic communication,

- strategic communication planning, integration, and synchronization processes,

- communication strategies and themes,

- communication, information, and influence capabilities and

- knowledge of human dynamics and analysis or assessment capabilities.

Hallahan (Hallahan et al., 2007, p. 9-11) suggests aspects that would to be implemented in communication strategy designing:

- The ability of communicators to differentiate between traditional communication channels and to choose the most effective ones.

- Important changes in public communication based on technology and by media economics.

- Usage of expanding variety of methods to influence on relationships and attitudes toward organizations.

- Strategic communication recognizes purposeful influence as the fundamental goal of communications by organizations.

According to van Ruler (van Ruler, 2018) strategic communication as the management of the amalgam of communication processes in the context of continuous strategy development, and therefore include the presentation, promotion, and realization aspects as well as the building and rebuilding aspects of strategy and see this as a continuous loop. Strategic communication follows strategy, and strategic communication is the aid with which to attain set goals by influencing the public sphere to accept these set goals.

Hallahan (2004) identified six communication specialties in organizations: management marketing, technical communication, political communication, public relations and information/social marketing campaigns. All listed areas of communication are in the pool of corporative communications and have a crucial impact on the company's mission fulfillment. The conclusion is that corporative communication is a structural part, or even more 'spine' of the company's strategic communication efforts.

As the main purpose of strategic communication Zerfass and Viertmann (Zerfass \& Viertmann, 2017) suggest: 
1. Enabling operations. Strategic communication raises publicity, attention, customer preferences, and employee commitment and thus keeps the organization running and ensures immediate success in terms of primary objectives.

2. Building intangible assets. Strategic communication builds a reputation, brands, and corporate culture and, thus, creates the immaterial assets that are the basis for sustainable long-term success.

3. Ensuring flexibility. Strategic communication builds relationships, trust, and legitimacy and, thus, secures the organization's license to operate and increases its room for maneuver.
4. Adjusting strategy. Strategic communication monitors the organization's environment, thus increasing the reflective capacities of strategic management decisions. This secures thought leadership, innovation potential, and crisis resilience.

As an overall conclusion of understanding of strategic communication in a role of business policy, organizational structure and mission fulfillment support, it could be said that SC belongs to the top strategic priorities for organizations, which strive to maximize its results.

\section{Strategic communication and integrated business communication}

Global economy disbalance indicates necessity for integrated marketing approach (Grubor, 2014), but also other integrated relations (Miller, 2014), such imply existing of integrated marketing communication. It is important to emphasize that strategic communication and integrated marketing communication have certain differences. Namely, strategic communication differs from integrated communication because its focus is on how an organization communicates across organizational endeavors. It is more likely that 'integrated business communication as a synergy of marketing and public relation activities of an organization towards internal and external public' (Filipović \& Kostić, 2011, p. 29), and on this way is closely related with strategic communication concept, but it is not very same. The main emphasis distinction is on the strategic application of communication, and how particular organization acting as a social actor to advance its mission. (Hallahan et al., 2007).

Furthermore, successful corporation with a strong reputation as a part of the genesis of integrated business communication, and an overall sense, part of strategic communication, is not just production and revenue orientated organization, but also recognized as a social responsible (Smith \& Kubala, 2018) or a 'good neighbour' and member of society. Namely, in research conducted regarding the connection of corporative reputation and corporative efficiency, Vlastelica et al. (Vlastelica, Kostić-Stanković \& Cicvarić Kostić, 2017, p.158) point to the possible divergence of 'hard' and 'soft' company business dimension:

1. Hard business dimension:

- Business performance (profitable, market leader, customer orientation, regulation obey)

- Working environment (desirable employer, professional and quality management, quality employees, sustainable job)

- Production and services (quality of product/services, innovative, security, and safety, a balance of price and quality).

2. Soft business dimension:

- Social responsibility (philanthropy, donation, environmentally friendly, local community responsibility, contribution to wide society).

- Marketing (intensity, creativity, responsibility, informative communication).

- Public relation (media relation, event organization, Internet communication, quality internal communication).

According to the given perspective of corporative social dimensions, it is clear that companies which attempt to develop successful and fruitful strategic communication, have to plan, implement and develop overall strategic corporative communication. In other words, a company that strives to achieve highest business results should understand and implement the concept of socially responsible business (Grubor, 2013).

Strategic corporative communication (in short, strategic communication) is not just integrated marketing communication, because it is also orientated towards the community as a social actor, corporative citizen, which indicates a much 
wider public policy, organizational and taskrelated connotations than integrated business communication (IBC). The suggestion is that IBC is a part of overall corporative communication, which is identified as SC implemented on the corporative level, and that volume of correlation between those two depends of strategic orientations and ambitions of an organization. Namely, a difference between IBC and SC is in particular orientation of organization and its ambition to introduce their own set of goals as an issue in wider public policies arena. Through the scope of implemented activities, SC cover a wide area of social, political and administrative actions (Figure 1).

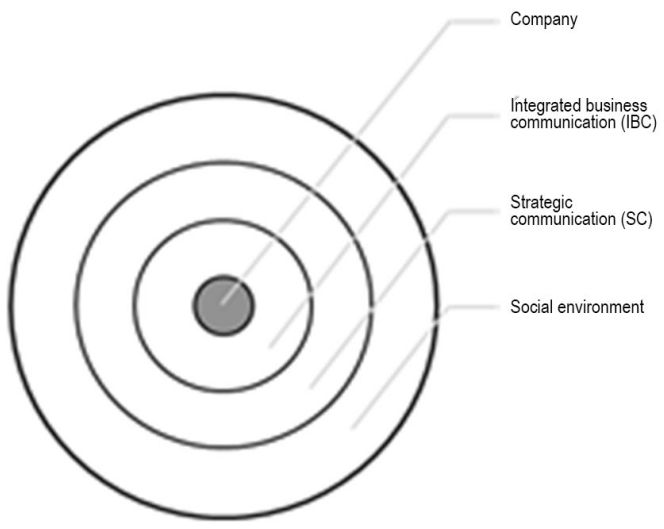

Figure 1 Communication of company trough IBC, a catalytic contribution of SC (white arrows) and feedback communication from social environment to the company (gray arrows) with wide input trough SC and more concrete in IBC area.

Source: The author

Thus, strategic communication covers a wide range of complex and strategically important communications: public affairs, advocacy, thinkthank group's relations, communication with other expert bodies, political activities, public policy engagement, activism, contribution to public diplomacy, etc. In short, strategic communication has a catalytic role in interference of companies' integrated business communication with the wide social environment.

\subsection{Strategic communication and political influence}

We could agree with Hallahan (Hallahan et al., 2007 , p. 24) that central issue of strategic communication is the idea of influence or "the power or capacity of causing an effect in indirect or intangible ways".

The ability to use corporate communication management methods allows "representatives of functional systems and special interest groups" to gain access to media and thus to gain political influence. Although the "actors of civil society" have less power than politicians and lobbyists, they too have the opportunity and do use strategic communication to affect the debate in the public sphere (Habermas, 2006, p. 15). Based upon all of the above, it could be suggested that corporative communication trough corporative political activities contribute toward fulfilment of the organizational mission. In this way, corporative political activities as a part of strategic communication attend to improve organizational mission achievement by conducting communication activities in interaction with political, lawmakers and other governmental or international institutions.

\subsubsection{Corporative political activities as a part of the company's strategic communication}

The contemporary business environment is complex and consists of market and nonmarket components (Baron, 1995; Boddewyn, 2003; Doh, Lawton, McGuire, \& Rajwani, 2013). Business environment indicates not just economic but social and political role of the company (Donaldson \& Preston, 1995; Wicks et al., 1994). Corporative Political Activity (CPA) is a part of a nonmarket strategy by which companies tend to achieve a corporative advantage in communication toward a wide public audience.

Furthermore, CPA significantly contributes toward improvements of the firm's position and overall company strength (Bonardi, Holburn, \& Bergh, 2006; Lawton et al., 2013; Schuler, Rehbein \& Cramer, 2002). More closely, CPA is recognized as a part of communication strategy for facilitating the development of trust between company and policymakers, mostly government institutions (Liedong, Ghobadian, Rajwani, \& O'Regan, 2014). Companies use different tactics for influence on government: through acts of political action committees (PAC) contributions, lobbying, and engaging in political support activism (e.g. Doh et al., 2012). Some research indicates that CPA has conditionally influence on a firm's efficiency (Hadani, Bonardi, \& Dahan, 2017), and other suggest that CPA is recognized as a nonmarket strategy that 'attempts to shape government policy in ways favorable to the firm' (Hillman, Keim, \& Schuler, 2004, p. 838).

In the scope of communication strategy, CPA is recognized as company's information related strategy which aims 'to affect public policy by 
providing specific information about preferences for policy or policy positions to policy-makers and may involve providing information on the costs and benefits of different issue outcomes' (Hillman \& Hitt, 1999, p. 834). Variety of CPA activities, areas, and strategic approach are wide and vivid: electoral campaigns, policy development, law and regulation contribution, expertise involvement or even entrance in foreign policy shaping (Mitrović, 2017, pp. 31-105).

In short, CPA is an approach by which government institutions, lawmakers, and regulatory proposition agencies could recognize ability or skills of firms in policy issues. Influence of CPA contains two dimensions of trust: integrity and policy ability/skill. CPA has implemented a form of strategic interest communication, usually recognized as lobbying or advocacy.

\subsubsection{Structuring the CPA strategy}

As key elements of CPA as an implemented form of lobbying are information, credibility, appropriate communication, ethics and legally based relations (Mitrović, 2017b).

As a possible base for designing of effective CPA strategy as a lobbying strategy, it could be taken a pattern of STAP (Static, Tangible, Action and Pressure) strategy development model (Mitrović, 2017c). Suggested STAP model of CPA designing is proposed upon on a result of research of numerous implemented lobbying strategies in different business areas (market and nonmarket) as well as in different social environment (cultural, regional, international) (Mitrović, 2017a, pp. 31-61). The suggested model consists of listed pillows, elaborated as follow:

Static - this phase considers analysis of all existing, contemporary, or 'given' parameters of all relevant political, business, cultural and marketing aspects of the environment in which our organization intends to have influence. Some of them are laws, state and institutional strategies, organizational procedures, customs, ethics, tradition, cultural environment, good and bad practice, trends. All those external parameters should be analysed though the perspective of an organization's aims (organizational, strategic, business, etc.). The aim of this phase is to build an analytical approach for defining our goals and may achieve them through the CPA strategy. The purpose of this phase is to connect all-important stakeholders, bearing in mind stakeholder theory approach (Buchholz \& Rosenthal, 2004; Driscoll
\& Starik, 2004; Hendry, 2003; Mahon, 2002), and project environment with goals of our lobbying project. The most effective approach is to make detailed analyses of all stakeholders and to try clarifying the interconnections, correlations and possible future trend in the area that represents our interest arena. The task that has to be accomplished in this phase is to connect the concerted goal of our organization with important facts that have an influence on our organizational success. In addition, the assignment is to create links between (our) organizational and goals of (our) lobbying campaign. This achievement is very important for evaluating phase of strategy implementation, as a measured result. In this way, we develop an instrument for measuring strategy efficiency. Final product of the Static phase should clarify stakeholders (number, influence strength, organizational form, etc.), goals (of lobbying campaign), characteristics of social environment (laws, bureaucracy structure, procedures of communication, costumes, ethics, and cultural habits), and perspective of future trends (policies, trends, strategies, analyses conclusions and forecast of future needs).

Tangible - the intention to recognize and systematize stakeholders and their inter-relations. By putting all the stakeholders and recognized static parameters in an actual dynamic correlational form, static variables became tangible, with a shape and interaction. The intensity, polarity and publicity dimensions show the interaction of stakeholders. Intensity shows how strong relation is regarding our subject from the stakeholder's point of view. Polarity implies a positive or negative stakeholder's attitude towards our interest. Public exposures of CPA lobbying processes declare how non-actors could notice lobbying activities. Assessment approach is developed on Anastasiadis's (2006) theory of accessibility of a lobbying process by nonparticipations. He recognizes four possible relations between lobbying process subjects and non-participations: 1. Public and transparent 'Seeing \& Hearing' mode; 2. Public, but opaque 'Blind' mode; 3. Transparent, but private - 'Deaf' mode; 4. Opaque and private - 'Blind \& Deaf' mode.

Placing all these impact factors (intensity, polarity, and publicity) in the same threedimensional coordination system, we can design a "Power Map" (PM) (figure 2). This is a basic point for developing the communication strategy. The conclusions produced by analysing 
correlations, impacts, value orientations, as well as previous experience of public expressions on our target issues are used in creation of an appropriate communication strategy. Bearing in mind that the final goal is to inform, influence, and to build alliances, the communication methods have to be considered carefully to avoid misunderstandings.

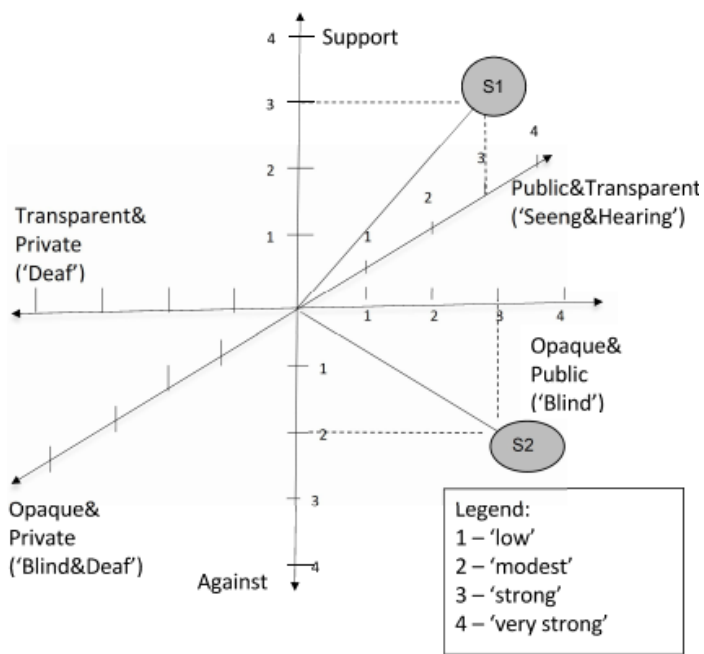

Figure 2 Power Map example: subject 1 has strong support, public, and transparency position toward lobbying issue; Subject 2 has moderate negative, and nonparticipants in the process couldn't see a process of lobbying (they are 'blind' for the process) Source: The author

Action - In this phase we develop, design, and impellent communication strategy. As Anastasiadis (2006) pointed out that communication is patiently essential in conveying information on preferences or positions. Lobbying simply cannot happen without it. Communication would thus appear to be the process, or action, by which lobbying happens. This phase is active based and means usage of communication instruments with a purpose to inform, expose, negotiate, promote and convince. Depending on situation, stakeholder's position and attitude regarding lobbying subject, we will choose some of communication instruments: one-to-one meeting, public hearing, public promotion, media covering story, publishing experts articles, using public debates, organized (or just take apart on) special events and all other wide range of PR tools to express our lobbying subject.

In this phase, very important is the use of evaluating tools, to measure the impact of our message in 'heart and mind' of a targeted audience, since expectable stakeholder's reaction and changing or powering altitude. Feedback data can provide us with evidence of any change in position on the PM and can help in rationalizing our use of resources (time, money, organization capacities, etc.). If during implementation we notice some changes, it is useful for redirecting the message and influence beam, encouraging alliance and coalition efforts at the same time. Because the CPA as lobbying strategy is a strategic orientated, we could not underestimate the importance of every specific, but also a wide public audience. That task request multidimensional approach in designing communication tactics and tools matrix (Table 1).

Table 1 Proposal of communication tactics and activities matrix

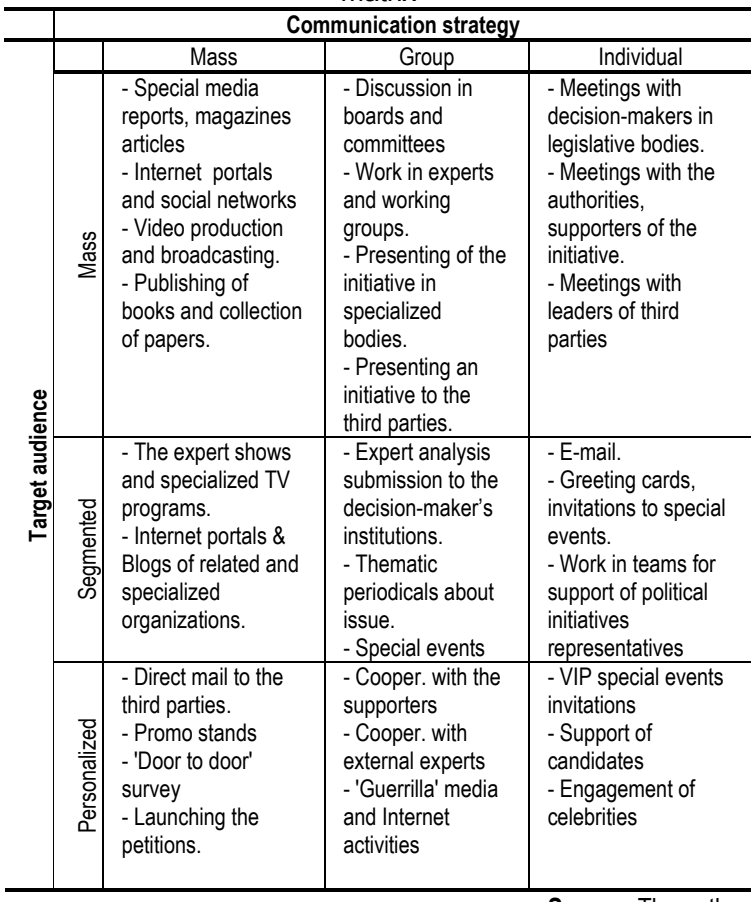

Source: The author

\section{Conclusion}

Strategic communication is the product of the actual needs of organizational entities to achieve a comprehensive and synergistic relationship with all segments of the public in their surroundings, in order to achieve maximum support for the accomplishment of their mission.

Strategic communication as a concept goes beyond the ontological but also the epistemological framework of integrated business communication, primarily in the segment of subjects in the process of communication, their genesis and understanding. Thus, strategic communication becomes synonymous with comprehensive corporate communication. A 
particular form of strategic correlation is corporative political activities. Through it, companies have an impact on a non-market segment of a society that is of high priority in relation to its business interests. The significance of these entities is their ability to influence laws and regulations on startup companies. Through a systemically organized approach to stakeholders representing decision-makers and legislators, the company realizes its interests and affirms itself as an active entity in the political public sphere. In process of planning the corporate political activity, it is useful to use planning analytical methods, which are systematized in the models of planning, as proposed and elaborated STAP model is.sm

\section{References}

Anastasiadis, S. (2006). Understanding corporate lobbying on its own terms. Research Paper Series. International Centre for Corporate Social Responsibility, Nottingham University No. 42-2006.

Argenti, P., Howell, R., \& Beck, K. (2005). The Strategic Communication Imperative.SPRING, 46 (3), 83-90.

Baron, D. P. (1995). Integrated strategy: Market and nonmarket components. California Management Review, 37 (2), 47-65. https://doi.org/10.2307/41165788

Boddewyn, J. J. (2003). Understanding and advancing the concept of "nonmarket." Business \& Society, 42, 297327. https://doi.org/10.1177/0007650303257504

Bonardi, J. P., Holburn, G. L. F., \& Bergh, R. G. V. (2006). Nonmarket strategy performance: Evidence from U.S. electric utilities. Academy of Management Journal, 49, 1209-1228. https://doi.org/10.5465/amj.2006.23478676

Buchholz, R. A., \& Rosenthal, S. B. (2004). Stakeholder theory and public policy: How governments matter. Journal of Business Ethics, 51(2), 143 - 153. https://doi.org/10.1023/B:BUSI.0000033608.61005.1f

Doh, J. P., Lawton, T. C., \& Rajwani, T. (2012). Advancing nonmarket strategy research: Institutional perspectives in a changing world. Academy of Management Perspectives, 26, 22-39. https://doi.org/10.5465/amp.2012.0041

Donaldson, T., \& Preston, L. E. (1995). The stakeholder theory of the corporation: Concepts, evidence, and implications. Academy of Management Review, 20, 6591. https://doi.org/10.5465/amr.1995.9503271992

Driscoll, C., \& Starik, M. (2004). The primordial stakeholder: Advancing the conceptual consideration of stakeholder status for the natural environment. Journal of Business Ethics, 49 (1), 55-73. https://doi.org/10.1023/B:BUSI.0000013852.62017.0e

Filipović, V. \& Kostić-Stanković, M. (2011). Odnosi s javnošću. Beograd: Fakultet organizacionih nauka.

FTL, Financial Times Lexicon. Retrieved October 10, 2018 from: http://lexicon.ft.com/Term?term=strategiccommunication
Grubor, A. (2013). Marketing Aspects of Socially Responsible Business. Strategic Management, 18 (3), 30-36.

Grubor, A. (2014). The Role of the Marketing Aspects of Market Integration in Achieving. Strategic management, 19 (2), 041-046.

Habermas, J. (2006). Political communication in media society-Does society still enjoy an epistemic dimension? The impact of normative theory on empirical research. Communication Theory, 16 (4), 411 426.

https://doi.org/10.1111/j.1468-2885.2006.00280.x

Hadani, M., Bonardi, J. P. \& Dahan, N. (2017). Corporate political activity, public policy uncertainty, and firm outcomes: A meta-analysis. Strategic Organization, 15 (3), 338-366.

https://doi.org/10.1177/1476127016651001

Hallahan, K. (2004). Communication management. In R. L. Heath (Ed.), Encyclopedia of public relation, 1 (pp. 161164). Thousand Oaks, CA: Sage.

Hallahan, K., Holtzhausen, D. R., Van Ruler, B., Verčič, D., \& Sriramesh, K. (2007). Defining strategic communication. International Journal of Strategic Communication, 1 (1), 3-35. https://doi.org/10.1080/15531180701285244

Hendry, J. R. (2003). Environmental NGO's and business: A grounded theory of assessment, targeting, and influencing. Business \& Society, 42 (2), 267- 276 https://doi.org/10.1177/0007650303042002005

Hillman, A. J., \& Hitt, M. A. (1999). Corporate political strategy formulation: A model of approach, participation, and strategy decisions. Academy of Management Review, 24, 825-842. https://doi.org/10.5465/amr.1999.2553256

Hillman, A. J., Keim, G. D., \& Schuler, D. (2004). Corporate political activity: A review and research agenda. Journal of Management, 30, 837-857. https://doi.org/10.1016/j.jm.2004.06.003

Holtzhausen, D., \& Zerfass, A. (2015) Strategic Communication: Opportunities and Challenges of the Research Area. In D. Holtzhausen \& A. Zerfass (Eds.) The Routledge Handbook of Strategic Communication (pp. 3-17). New York: Routledge. https://doi.org/10.4324/9780203094440

Holtzhausen, R. (2002). Towards a postmodern research agenda for public relations. Public Relations Review, 28, 251-264. https://doi.org/10.1016/S0363-8111(02)00131-5

Holtzhausen, R. (2008). Strategic communication. In W. Donsbach (Ed.), The International Encyclopedia of Communication, 10 (pp. 4848-4855). Malden, MA: Blackwell. https://doi.org/10.1002/9781405186407.wbiecs106

Holtzhausen, R., \& Zerfass, A. (2013). Strategic communication-Pillars and perspectives on an alternate paradigm. In K. Sriramesh, A. Zerfass, \& J.-N. Kim (Eds.), Current Trends and Emerging Topics in Public Relations and Communication Management, (283-302). New York: Routledge. https://doi.org/10.1007/978-3-531-18961-1 4

Lawton, T. C., McGuire, S., \& Rajwani, T. (2013). Corporate political activity: A literature review and research agenda. International Journal of Management Reviews, 15, 86-105. https://doi.org/10.1111/j.1468-2370.2012.00337.x 
Liedong, T., Ghobadian, A., Rajwani, T. \& O'Regan, N. (2014). Toward a View of Complementarity: Trust and Policy Influence Effects of Corporate Social Responsibility and Corporate Political Activity. Group \& Organization Management, 40 (3), 405-427. https://doi: $10.1177 / 1059601114560064$

Mahon, J. F. (2002). Corporate reputation: A research agenda using strategy and stakeholder literature. Business \& Society, 41(4): 415-445. https://doi.org/10.1177/0007650302238776

Miller, A. (2014). The Role of Integrating Relations - Interenterprise and Intra-enterprise Interaction. Strategic Management, 19 (3), 10-17.

Mitrović, M. (2017a). Strategic lobbying: Practice and models for the development of influence communication strategy. Sarbrucken: LAP LAMBERT Academic Publishing.

Mitrović, M. (2017b). Lobbying - Managing with Strategy Orientated Communication, Retrieved September, 18, 2018 from SSRN:

https://papers.ssrn.com/sol3/papers.cfm?abstract id=2 942002 https://doi.org/10.2139/ssrn.2942002

Mitrović, M. (2017c). Lobbying Strategy - 'STAP' Model. Retrieved September, 18, 2018 from SSRN: https://papers.ssrn.com/sol3/papers.cfm?abstract id=2 956230 https://doi.org/10.2139/ssrn.2956230

OB Oxford Bibliographies. Retrieved September 10, 2018 , from: http://www.oxfordbibliographies.com/view/document/ob o-9780199756841/obo 9780199756841-0007.xml

Paul, C. (2011). Getting Better at Strategic Communication. Santa Monica: RAND.

\section{$\triangle$ Correspondence}

\section{Miroslav Mitrović}

Strategic Research Institute, University of Defense, 38 Neznanog junaka str., 11000, Belgrade, Serbia E-mail: mitrovicmm@gmail.com
Schuler, D. A., Rehbein, K., \& Cramer, R. D. (2002).

Pursuing strategic advantage through political means: A multivariate approach. Academy of Management Journal, 45, 659-672 https://doi.org/10.2307/3069303

Smith, S., and Kubala, P. (2018). Social justice in the workplace: Are on-demand companies exploiting current regulatory ambiguities and workforce precarity? Psychosociological Issues in Human Resource Management, 6(1), 166-171. https://doi.org/10.22381/PIHRM6120188

Thorson, K. (2013). Strategic communication. Retrieved October 10, 2018, from:

http://www.oxfordbibliographies.com/view/document/ob o-9780199756841/obo-9780199756841-0007.xml.

van Ruler, B. (2018). Communication Theory: An Underrated Pillar on Which Strategic Communication Rests. International Journal of StrategicCommunication, 12 (4), 367-381. https://doi.org/10.1080/1553118X.2018.1452240

Vlastelica, T., Kostić-Stanković, M. \& Cicvarić Kostić,S. (2017). Konceptualni pristupi modeliranju korporativne reputacije.Marketing, 48 (3), 155-160. https://doi.org/10.5937/Markt1703155V

Wicks, A. C., Gilbert, J., Daniel, R., \& Freeman, R. E. (1994). A feminist reinterpretation of the stakeholder concept. Business Ethics Quarterly, 4, 475-497. https://doi.org/10.2307/3857345

Zerfass, A., \& Viertmann, C. (2017). Creating business value through corporate communication: A theorybased framework and its practical application. Journal of Communication Management, 21 (1), 68-81. https://doi.org/10.1108/JCOM-07-2016-0059 